\title{
Role of Panchatikta Panchaprasutik Niruha Vasti in Prediabetes A case report
}

\author{
Case Report
}

\section{Poonam V Ashtankar ${ }^{*}$, Punam Sawarkar²}

1. P.G Scholar, 2. Associate Professor, Department of Panchakarma, MGACH \& RC, Salod (H), Wardha.

\begin{abstract}
Background: Prediabetes is an intermediate state of hyperglycemia with glycaemic parameters above normal but below the diabetes threshold. In Ayurveda, it is correlated with Prameha Poovaroopavastha. The risk of developing diabetes remains high with an annual conversion rate 5-10\%. Many other studies have shown that the efficacy of lifestyle intervention in diabetes prevention with a relative risk reduction of $40-70 \%$ in prediabetes adults. If we treat this disease in early stage then it checks the further pathogenesis of disease. Aim and objectives: The aim of this study was to observe the efficacy of Panchatikta Panchaprasutik Niruha Vasti enema including Palliative treatment in prediabetes. Methods: It is a single case study of 55 years old male patient who was diagnosed with prediabetes correlated as Prameha Poorvaroopa from 1 year approached to Ayurvedic hospital and was treated Panchatikta Panchaprasutik Niruha Vasti. The treatment was continued for consecutive 15 days. Results: After 15 days changes were observed in symptoms as well as reduction was seen in blood and urine sugar level and overall quality of life of patient was improved. Conclusion: Patient got satisfactory relief in symptoms as well as objective parameters after 15 days.
\end{abstract}

Key Words: Prediabetes, Panchatikta Panchaprasutik Niruha Vasti, Prameha poorvaroopa.

\section{Introduction}

Ayurveda is a holistic science which gives more emphasis over prevention of disease rather than curing of disease. Many clinical entities eg. Diabetes, obesity can be prevented with appropriate Dietic habit and suitable lifestyle modification. Prediabetes is an intermediate state of hyperglycemia with glycaemic parameters above normal but below the diabetes threshold. The risk of developing diabetes remains high with an annual conversion rate 5-10\% (1). In Ayurvedic compendium Prameha is defined to be characterized with excessive urination (both in frequency \& quantity) and turbidity (2). Prameha is a Tridoshaj Kapha predominant disease (3). Which is included in Ashtamahagada (eight types of major diseases) by Acharya Charaka, Sushruta and Vagbhata. Prameha Poorvaroopavastha (prodromal features) explained in our ancient Samhitas can be correlated with prediabetes condition. If we manage the disease at an early stage, it will check for further disease pathogenesis. Thus, diagnosis and preventive steps in Poorvaroopavastha (fourth Kriyakala) (4) are very much appreciated.

Today's eating habits, sedentary lifestyle and genetics can also play role for putting disturbances on

\section{* Corresponding Author:}

Poonam V. Ashtankar

PG Scholar, Department of Panchakarma,

MGACH \& RC,

Salod $(\mathrm{H})$,

Wardha, India

Email Id: drashtankarpoonam@,gmail.com the usual health. Several studies have demonstrated the effectiveness of lifestyle measures in diabetes care with a relative risk reduction of 40-70 per cent in adults. So, there are more chances to develop prediabetes. Type 2 diabetes may develop within 10 years if the prediabetic condition is not controlled by appropriate lifestyle changes. One study found that 5 to $7 \%$ weight loss appears to reduce the risk of diabetes (5). Many patients are reluctant to do lifestyle modification and they prefer for specific treatment so they approach for Ayurvedic physician. Considering this fact, it is need of hour to search some alternative therapy in Ayurveda to check over the pathogenesis of prediabetes to avoid its further progress into diabetes condition.

The main treatment principle in the condition of prediabetes is the elimination of Kleda (wetness). Shodhana Chikitsa (purificatory treatment) is the best choice of treatment for Kledaharana since Prameha is Bahudoshavastajannya Vyadhi (6). Vagbhata has mentioned about 5 types of Shodhana (Purgatative) treatment modalities which are known as Panchashodhana (five penta bio purificatory procedure). Niruha Vasti (decoction enema) is one of them (7). Among Panchakarma Vasti is such an invasive therapy having multidimensional effect. Among various Vasti preparations, Panchatikta Panchaprasutik Niruha Vasti is specially narrated for the management of Prameha (8). which has cardinal signs and symptoms e.g. Prabhut Mutrata (excessive urination), Ghanangata (heaviness of body) Atiswedapravriti (excessive sweating), Karapada Daha (burning sensation in hands and feet) (9). In this case study, a 55-years old man with Prediabetes was prescribed Panchatikta Panchaprasutik 
Poonam V. Ashtankar et.al., Role of Panchatikta Panchaprasutik Niruha Vasti in Prediabetes - A case report

Niruha Vasti along with specific palliative treatment,which showed excellent result as improvement in symptoms as well as reduction in Blood and urine sugar levels.

\section{Material and Methods}

It is a single case study. Informed consent was taken from the patient in his own language.

\section{History of present illness}

A 55 year old man having Demographic detail mentioned in Table 1. He was apparently well before 1 years. While undergoing his annual checkup, he was diagnosed as prediabetes. So he approached to Panchakarma OPD, Mahatma Gandhi Ayurved Medical College Hospital and Research Centre, Wardha, Maharashtra, India for Ayurvedic treatment Considering all clinical symptoms like Prabhut Mutrata (excessive urination) from 1 years, Ghanangata (heaviness of body) since 1 years, Ati Swedapravriti (excessive sweating ) present in that patient since 1years, Karapada Daha (burning sensation in hands and feet) since 6 months which are mentioned in Table 2. He had associated symptoms of weight gain since 6-7 years, distention of abdomen since 1-2 years and Itching over inguinal region from 6 months. Panchtikta Panchprasutik Niruha Vasti $(540 \mathrm{ml})$ was administered to him along with specific palliative treatment (Chandraprabha Vati , Arogyavardhini Vati and Gandharva Haritaki Churna) was prescribed, Without stopping his concomitant medication . Ashtavidha Pariksha with vitals examinations are mentioned in Table 3 and 4 respectively.

Table no.1 : Demographic Details

\begin{tabular}{l|l}
\hline Name: & XYZ \\
\hline Age: & 55 years \\
\hline Sex: & Male \\
\hline Address: & Chimur \\
\hline OPD - & 1911150034 \\
\hline Occupation: & Retired PHC worker \\
\hline Marital status: & Married \\
\hline Socio- economic status: & Middle class \\
\hline Weight: & $80 \mathrm{~kg}$ \\
\hline Height: & $169 \mathrm{~cm}$ \\
\hline
\end{tabular}

Table no. 2 : Chief Complaints with its duration

\begin{tabular}{|c|c|c|c|}
\hline A. & Chief complaints & Grade & Duration \\
\hline 1 & Excessive urination & $1(+)$ & 1 years \\
\hline 2 & Heaviness of body & $4(+)$ & 1 years \\
\hline 3 & Excessive sweating & $2(+)$ & 1 years \\
\hline 4 & $\begin{array}{c}\text { Burning sensation in } \\
\text { hands and feet }\end{array}$ & $2(+)$ & 6 months \\
\hline B. & $\begin{array}{c}\text { Associated } \\
\text { complaints }\end{array}$ & Grade & Duration \\
\hline 1 & $\begin{array}{c}\text { Weight gain } \\
\text { Distention of } \\
\text { abdomen }\end{array}$ & $3(+)$ & $6-7$ yrs \\
\hline 3 & $\begin{array}{c}\text { Itching over inguinal } \\
\text { region }\end{array}$ & $3(+)$ & $1-2$ yrs \\
\hline & 6 month \\
\hline
\end{tabular}

\section{Table no. 3 : Ashtavidha Parikshana}

\begin{tabular}{|l|l|}
\hline Nadi $($ Pulse) & 64/min \\
\hline Mala (Stool) & Saam (Distention of abdomen) \\
\hline Mutra (Urine) & Asamyak \\
\hline Jeevha (Tongue) & Alpasaam \\
\hline Shabda (Speech) & Spashta \\
\hline Sparsha (Skin) & Anushanasheeta \\
\hline Druka (Eyes) & Prakruta \\
\hline Aakruti (Posture) & Shtool \\
\hline
\end{tabular}

Table no. 4 : Vitals Examination

\begin{tabular}{|l|l|}
\hline Blood Pressure (B.P) & $140 / 80 \mathrm{~mm} / \mathrm{Hg}$ \\
\hline Pulse (P) & $64 / \mathrm{min}$ \\
\hline Respiratory Rate (RR) & $18 / \mathrm{min}$ \\
\hline
\end{tabular}

\section{Past History}

Patient was also known case of hypertension since 10 years with its regular treatment.

\section{Medication History}

- Tablet Amlodipine $5 \mathrm{mg}$ daily once For 10 years.

Personal history

- Food habits: mixed diet, craving for Sweet, salty and pungent food items

- Sleep: sound

- Addiction: alcohol (once in a week) and tobacco (twice a day)

\section{Family History}

- Father was known case of DM and sibling was obese.

Nidan Panchak (Etiopathogenesis of Prameha Poorvaroopa in Ayurveda)

- Hetu (etiology or causative factors)

- Ahara: Madhur, Lavana, Katu Rasatmak Ahar (Sweet, salty, and spicy food items)

- Vihara: Asayasukham (Habituation to sitting on soft cushions for long periods), Swapnashayan (excessive sleeping), Diwaswap (day sleep)(10)

- Roopa ( Manifestation) : Excessive urination, heaviness of body, excessive sweating, burning sensation in hands and feet (9).

- Samprapti (patho-physiology of the disease): Due to above factors leads to aggravation of Tridosha, Saptadhatu and Mansik Dosha and forms the symptoms of Prameha Poorvaroopa (11).

\section{Investigations done \\ - Blood sugar level \\ - Urine sugar \\ - Fasting and Post prandial}

\section{Diagnosis}

Prediabetes (Prameha Poorvaroopa).

\section{Treatment Advised}

By analyzing the above pathogenesis of disease in this patient, medicated enema and palliative treatment was prescribed which are shown in table no. 5 and 6 respectively. 


\section{Table no. 5 : Shodhana Chikitsa}

\section{Shodhana Chikitsa}

Drugs

Duration

Tila Talia

Abhyang
foot)

Nadi Sweda (Local - lumbar to Nirgundi Patra

both foot for 5 minutes)

Panchatikta Panchaprasutik Niruha Vasti
15 days

15 days

Kala Vasti

(15 days)
-Patol (Trichosanthes dioca. Roxb.)

-Nimba(Azadiracta indica.Juss.)

- Bhunimba(Andrographis paniculata.Linn.)

-Rasana (Pluchealanceolata.C.B.Clarke)

-Saptaparna(Alstonia scholaris.R.Br.)

-Saindhava - 10gm

-Madhu - 15ml

-Goghrita-80ml

Table no.6 :Shamana Chikitsa

\begin{tabular}{|l|l|l|l|l|} 
Drugs & Dose & $\begin{array}{l}\text { T i m e of } \\
\text { Administration }\end{array}$ & Anupana & Duration \\
\hline Gandharvaharitaki Churna & $10 \mathrm{gm} \mathrm{Hs}$ & After food & Lukewarm water & 15 days \\
\hline Chandraprabha Vati & $250 \mathrm{mg} \mathrm{2} \mathrm{BD}$ & After food & Lukewarm water & 15 days \\
\hline Arogyavardhini Vati & $250 \mathrm{mg} 2 \mathrm{BD}$ & After food & Lukewarm water & 8 days
\end{tabular}

\section{Observation and Results}

After treatment, the patient had found significantly relief symptoms such as excessive urination, heaviness of body, excessive sweating and burning sensation in hands and feet and. There was significant result that $3 \mathrm{~kg}$ weight loss was observed after treatment . Assessment of the patient was carried out by reduction in gradation(12) of clinical symptoms and reduction in blood and urine sugar levels (Fasting and post prandial) on the day of primary assessment and on $15^{\text {th }}$ day. Shown in Table 7.

Table no. 7 : Assessment on the basis of subjective and objective criteria

\section{Type of assessment}

\section{A)Subjective criteria}

Excessive urination

Heaviness of body

Excessive sweating

Burning sensation in hands and feet

Weight gain

Distention of abdomen

Itching over inguinal region

B)Objective criteria

1)Blood sugar level

-Fasting

- Post prandial

2) Urine sugar

\section{Before treatment}

$1(+)$

$4(+)$

$2(+)$

$2(+)$

$3(+)$

$4(+)$

$3(+)$

$121 \mathrm{mg} \%$

$197 \mathrm{mg} \%$

-Present
After treatment

0

\section{1}

0

0

1

1

0

$85 \mathrm{mg} \%$

$130 \mathrm{mg} \%$

-Absent

Table no. 8 : Gradations for Subjective Criteria

\begin{tabular}{|c|c|c|c|c|c|c|c|}
\hline $\begin{array}{l}\text { Sr. } \\
\text { No }\end{array}$ & $\begin{array}{l}\text { Subjective } \\
\text { Criteria }\end{array}$ & Grade-0 & Grade-1 & Grade-2 & Grade-3 & Grade-4 & Grade-5 \\
\hline 1 & $\begin{array}{l}\text { Excessive } \\
\text { urination }\end{array}$ & $\begin{array}{l}3-5 \text { times } \\
\text { per day, no } \\
\text { rarely at } \\
\text { night }\end{array}$ & $\begin{array}{l}6-8 \text { times per } \\
\text { day, } 1-2 \text { times } \\
\text { per night }\end{array}$ & $\begin{array}{l}\text { 9-11 times per } \\
\text { day, } 3-4 \text { times } \\
\text { per night }\end{array}$ & $\begin{array}{l}>11 \text { times per } \\
\text { day, } 4 \text { times } \\
\text { per night }\end{array}$ & & \\
\hline 2 & $\begin{array}{l}\text { Heaviness } \\
\text { of body }\end{array}$ & $\begin{array}{l}\text { No } \\
\text { Heaviness }\end{array}$ & $\begin{array}{l}\text { Occasionally } \\
\text { feeling of } \\
\text { heaviness for } \\
\text { sometimes in } \\
\text { hand and feet. }\end{array}$ & $\begin{array}{l}\text { feeling of } \\
\text { heaviness for } \\
\text { sometimes in } \\
\text { hand and feet, } \\
\text { not affecting } \\
\text { daily activities }\end{array}$ & $\begin{array}{l}\text { Daily feeling } \\
\text { of heaviness } \\
\text { over body, } \\
\text { which leads to } \\
\text { Akarmanyata }\end{array}$ & $\begin{array}{l}\text { Most part of } \\
\text { body for long } \\
\text { duration }\end{array}$ & $\begin{array}{l}\text { All body, for } \\
\text { most part of } \\
\text { the body. }\end{array}$ \\
\hline
\end{tabular}


Sweating

after heavy

Excessive sweating

fast

movement

or in hot

cold weather

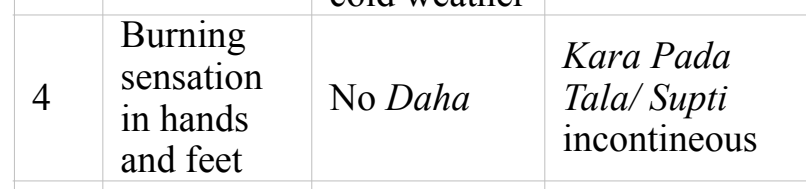

\begin{tabular}{|l|l|l|l|}
5 & $\begin{array}{l}\text { Distention } \\
\text { of } \\
\text { abdomen }\end{array}$ & $\begin{array}{l}\text { No } \\
\text { Adhmana }\end{array}$ & $\begin{array}{l}\text { Occasionally } \\
\text { feeling of } \\
\text { Adhmana }\end{array}$ \\
\hline
\end{tabular}

$6 \quad \begin{aligned} & \text { Dryness of } \\ & \text { Skin }\end{aligned}$
Profuse sweating after moderate work and movement

Kara Pada
Tala/ Supti
continuous but
not severe
Daily After
intake of food
up to 1 hour
with mild
distention of
abdomen
Lining and
even words
can be written
by nail

Profuse

Sweating after little work and movement sweating after little work and movement

Kara Pada Tala/Supti continuous and severe. distention of abdomen up to 1-3 hour after intake of food

Excessive

Rukshata leading to Kandu
Sweating

even at rest or cold weather

\begin{tabular}{|l|l|}
$\begin{array}{l}\text { Moderate } \\
\text { distention of } \\
\text { abdomen up } \\
\text { to 6 hours } \\
\text { after intake } \\
\text { of food }\end{array}$ & $\begin{array}{l}\text { Severe } \\
\text { distention of } \\
\text { abdomen up } \\
\text { to more } \\
\text { than6 hrs } \\
\text { after intake } \\
\text { of food }\end{array}$ \\
$\begin{array}{l}\text { Rukshata } \\
\text { leading to } \\
\text { crack } \\
\text { formation }\end{array}$ & \\
\hline
\end{tabular}

Table 9: Showing American Diabetic Association diagnostic criteria for normal glucose, Prediabetes, and diabetes II (13)

\begin{tabular}{|l|c|c|c|}
\multicolumn{1}{|c|}{ Diabetes test } & Normal & Prediabetes & Diabetes \\
\hline Hemoglobin Alc \% & $<5.7$ & $5.7-6.4$ & $\geq 6.5$ \\
\hline Fasting blood sugar, mg/dL & $<100$ & $100-125$ & $>125$ \\
\hline Post prandial blood sugar mg/dL & $<140$ & $140-199$ & $>199$ \\
\hline
\end{tabular}

\section{Discussion}

Considering all factors involved in the pathogenesis of Prameha Poorvaroopa, the main treatment principle is to remove Kleda in this case and Vasti Karma was already told by Acharya Charaka as it corrects the vitiation of Vata to stabilize its normal functions and also counteracting the vitiated Kapha, $K l e d a$, and Meda by using specific drugs. So specially prepared medicated enema was prescribed in this case followed by palliative therapy. After 15 days, patient got significant relief clinically as well as improvement were observed in blood and urine sugar level shown in Table 7. Given treatment protocol mainly comprises of Kledaharana, which helps the breakdown of pathogenesis of prediabetes in this patient. given below:

Probable mode of action of all interventions are

\section{Shoshanna Chikitsa}

Abhyanga (Local massage - From lumbar to both feet) with Tila Taila followed by Nadi Sweda (sudation) - Before administration of Niruha Vasti, local Snehana and Swedana given to the patient as a preprocedural protocol of Vasti. Local Snehana helps to pacify Vata, softness of the body, removes Mala and local Swedan relives stiffness, toughness, coldness and improves local blood circulation due to dilation of the blood vessels(14). Generally Tila Taila (sesame oil) is considered as best among all Tailas in Ayurveda(15) because it is Tridoshghna (subside all three Doshas) in nature and it nourishes tissues, gives strength and increases Agni (15). Nadi Sweda with the decoction of Nirgundi Patra is a kind of sudation in which medicated steam is applied to the patient's body. Nirgundi Patra has Vatahara, Shoolhara property(16). It relieves the pain and stiffness. But in this is case, both of these treatment are applied as a part of protocol \& to increase blood circulation with enhancement of effect of Niruha Vasti.

\section{Panchatikta Panchaprasutik Niruha Vasti-}

Panchatikta Vasti is specially prescribed for Prameha in Charaka Samhita(10) in Kaphaja Prameha, being an Abhishyanda Pradhana disease. Prameha is the perfect indication for the use of this type of Kledahara \& Shodhana Vasti. It is also a disease with a large Dushya Sangraha involved in its Samprapti (pathogenesis) (17). All the contents of this Vasti are Tikta Rasatmak, Katu Vipaki and Ushna Viryatmak so Deepan Pachan, Anulomak and Krumighna in nature(18).

- Patol - It is Dushta Kaphanashaka Dravya and useful in Agnimandya and Yakritvikar. It dilates opening of minute channels associated with Pakwashaya and expels dosha in the form of loose motion hence it should be used in Udar and Prameha Vikar for excretion of Kleda(19).

- Nimba - Digest and absorb Drava, Kapha and Kleda present in various Dhatus by its Tikta and Ruksha Gunas and controls Bahumutrata (20).

- Bhunimba - Bhunimba is useful in Yakrit Pleeha Vikar, Vibandha and Agnimandya(21). 
- Rasna- It is Vatakaphagna in nature so act in Prameha and Udar Vikar(22).

- Saptaparna - Useful in liver debility as liver stimulant due to Tikta Rasa. Since Tikta Rasa, it liquefies Kapha and eliminates it. Also acts as a Krimighna. It should be used in Hridayroga and vitiation of blood being Hridaya and alternative due to Tikta and Kashaya Rasa so, it is used in this case(23).

- Sarshpa Kalka - Used in the Vasti due to its Kaphavataghna, Deepan and Krimighna property. It is especially useful in reduce Pleehavriddhi hence it is best medicine for enlargement of spleen according to Aacharya Kashyapa. Also hridayouttejak and useful in Mutraghata, Mutrasanga and Kushtha(24)

- Saindhava (Rock salt) - It has properties such as Vishyandi, Sukshma, Tikshna, Ushna, and Vatghna encourages the evacuation of bladder and rectum Besides this, Sandhava kills the properties of Picchila, Bahula and Kashaya of Madhu, and it is closely related to form a homogeneous mixture. The use of rock salt is useful in the correction of electrolyte imbalance also (25).

- Madhu (Honey) - which has a prebiotic index of 6.89, due to its oligosaccharides(24). With this, honey helps grow a healthy microbial flora. Fructose and glucose, the main carbohydrate in honey, have same molecular formula, but different structural formula(26). Fructose helps to reduce the amount of hyperglycemia or obesity in these patients(27).

- Go Ghrita - Due to the lipid soluble nature, Vasti Dravyas mixed with ghee are readily absorbed into the rectum. As the rectum has a rich supply of blood and lymph (28).

\section{Shaman Chikitsa}

- Chandraprabha Vati-It cures the twenty varieties of Prameha. It relieves Vata, Pitta and Kapha. Due to an increase in the frequency of urination, abdomen distention and Itching purpose, Chandrapha Vati prescribed in this patient (29).

- Arogyavardhini Vati - - It provides total health and frees the body from all kinds of diseases because it balances the three Dosha. In this condition it is beneficial for the removal of excess fat, for the degradation of various types of toxins from the body and for the reduction of accumulated cholesterol in the body. It is also beneficial as a hepatoprotective, cardioprotective and digestive properties. (30).

- Gandharva Haritaki churna - Gandharva Haritaki Churna has Vatahara and Ruksha Virechak properties. In this patient it is indicated in the management of distention of abdomen as it is Anulomak in nature. It also potentiates the over all absorption of medicine(31).

\section{Conclusion}

The overall effect of above mention therapy reveals that prediabetes can be cured effectively with collaborative approached including Panchatikta Panchaprasutik Niruha Vasti and Palliative treatment without causing any adverse effect. It can be alternative therapy in current era for prediabetes. Now it is a need of hour to conduct trial with similar intervention in large sample size because it is a single case study to establish specific guidelines for the management of prediabetes \& to generate evidence based research for upcoming researchers in future.

\section{References}

1. Bansal N, Prediabetes diagnosis and treatment: A review. World J Diabetes 2015; 6(2): 296-303 Available from: URL: http:/www. wjgnet.com/ 1948-9358/full/v6/i2/296.htm DOI: http://dx.doi. org/10.4239/wjd.v6.i2.296.

2. Tripathi B, editor. Nidansthana; Pramehanidana Adhyaya. Vagbhat a, AshatangHrudaya. Chapter 10, Verse 7. Delhi, India: Chaukhamaba Sanskrit Pratishthan; 2015. p. 495.

3. Shukla V, Tripathi R, editor. Nidansthana; Prameha Nidana Adhyaya.Verse 3,8. In: Agnivesh ,Charak Samhita. Delhi, India: Chaukhamba Sanskrit Pratisthana; 2011. p. 501,503.

4. Sharma A, editor. Sutrasthana; Vranaprasnadhyaya. Verse 33.In: Sushrut, Sushruta Samhita Varanasi, Ind i a Ch a k k a m a S u b a rat i Prakashana,2015.p.90.

5. American Diabetes Association and National Institute of Diabetess, Digestive and Kidney Diseases. The prevention or delay of type 2 diabetes. Diabetes Care 2002; 25: P.742-749.

6. Shukla V, Tripathi R, editor. Chikitsasthana; Prameha chikitsa Adhyaya.Verse 51. In: Agnivesh , Charak Samhita. Delhi, India: Chaukhamba Sanskrit Pratisthana; 2011. p. 176.

7. Tripathi B, editor. Chikitsasthana;PramehachikitsaAdhyaya.Vagbhata, AshatangHrudaya. Chapter 13, Verse 2-3. Delhi, India: Chaukhamaba Sanskrit Pratishthan; 2015. p. 715.

8. Shukla V, Tripathi R, editor. Sidhistana; Prasruyogiya siddhi Adhyaya.Verse 8. In: Agnivesh ,CharakSamhita. Delhi, India: Chaukhamba Sanskrit Pratisthana; 2011. p.938.

9. Shukla V, Tripathi R, editor. Chikitsasthana; Prameha chikitsa Adhyaya.Verse 13-15. In: Agnivesh, Charak Samhita. Delhi, India: Chaukhamba Sanskrit Pratisthana; 2011.p. 170.

10. Shukla V, Tripathi R, editor. Chikitsasthana; Prameha chikitsa Adhyaya.Verse 4. In: Agnivesh, Charak Samhita. Delhi, India: Chaukhamba Sanskrit Pratisthana; 2011. p. 167.

11. Shukla V, Tripathi R, editor. Nidansthana; Prameha Nidana Adhyaya.Verse 5. In: Agnivesh , Charak Samhita. Delhi, India: Chaukhamba Sanskrit Pratisthana; 2011. p. 502.

12. Baghel MS. Textbook of Developing Guidelines for Clinical Research Methodology in Ayurveda. Institute for Postgraduate Teaching and Research in Ayurveda. Jamnagar, India: Published by Gujarat Ayurveda University; 2011. p. 65-68. 
13. Tuso P, Prediabetes and Lifestyle Modification: Time to Prevent a Preventable Disease. The Permanente Journal/ Summer 2014/ Volume 18 No. 3.

14. Pande P, Deshpande P. Osteoarthritis (Sandhigata Vata) in geriatric and its management with Kala basti: Research Article. World Journal of Pharmaceutical and Life Sciences wjpls, 2017, Vol. 3, Issue 5, 146-149.

15. Joseph R, Cherian A. Role of (oil massage) to lead a healthy life. Ayurpharm Int J Ayur Alli Sci., Vol.1, No.7 (2012) Pages 163 - 167.

16. Patil R. Compatrative study of Effect of Nirgundi Patra Piinda Sweada and Nadi Sweda in Katishool. Tilak Maharashtra Vidyapeeth, Pune .Desember2016.

17. Dimble M, Joshi Y, Asutkar V. Study of role of Panchatikta Basti in Abhishyanda Pradhana Prameha . Journal of Dental and Medical Sciences (IOSR-JDMS) e-ISSN: 2279-0853, p-ISSN: 2279-0861.Volume 16, Issue 4 Ver. VI (April. 2017), PP 64-68.

18. Deshpande AP, Subhash R, editors. Textbook of Dravayguna Vigyan (English), Part-2, A.R. Nandurkar, Shaniwar Peth, India: Proficient Publishing House; 2007.

19. Deshpande AP, Subhash R, editors. Textbook of Dravayguna Vigyan (English), Part-2, A.R. Nandurkar, Shaniwar Peth, India: Proficient Publishing House; 2007. p. 419-421.

20. Deshpande AP, Subhash R, editors. Textbook of Dravayguna Vigyan (English), Part-2, A.R. Nandurkar, Shaniwar Peth, India: Proficient Publishing House; 2007. p.325-328.

21. Deshpande AP, Subhash R, editors. Textbook of Dravayguna Vigyan (English), Part-2, A.R. Nandurkar, Shaniwar Peth, India: Proficient Publishing House; 2007. p.846.

22. Deshpande AP, Subhash R, editors. Textbook of Dravayguna Vigyan (English), Part-2, A.R.
Nandurkar, Shaniwar Peth, India: Proficient Publishing House; 2007. p. 949-950.

23. Deshpande AP, Subhash R, editors. Textbook of Dravayguna Vigyan (English), Part-2, A.R. Nandurkar, Shaniwar Peth, India: Proficient Publishing House; 2007. p. 479-481.

24. Deshpande AP, Subhash R, editors. Textbook of Dravayguna Vigyan (English), Part-2, A.R. Nandurkar, Shaniwar Peth, India: Proficient Publishing House; 2007. p.664-665.

25. Auti S, Jadhava N, Thakar A. Basti (medicated enema)- An alternative in prevention and management of diabetes. Ayurpharm Int J Ayur Alli Sci., Vol.2, No.11 (2013) Pages 350 - 356.

26. The chemistry of carbohydrates found in food. Retrieved from: http://www.medbio.info [Accessed on: $15 / 5 / 2020]$.

27. Vaisman N, Niv E, Izkhakov Y, Catalytic amounts of fructose may improve glucose tolerance in subjects with uncontrolled non-insulin-dependent diabetes. Clinical Nutrition 2006; 25: 617-21.

28. Chalapathi R, Lakshmi V, Goud R, Rasamrut V. Efficacy of Yogabasti Comprising of Panchatikta Niruha Basti \& Madanaditaila Anuvasanabasti in the Management of Kitibha Kushta Vis-⿳亠厶⺝-Vis Psoriasia. Ayurveda e-Journal Rasamruta, 4:4, June 2012.

29. Mishra S, editor. Mandagani Chikitsa Prakarana. Verse 102-110. In: Govind D. Bhaisajyaratnavali. Varanasi, India: Chaukhamba Surbharati Prakashan; 2007. p. 521-522.

30. Pal S, Ramamurthy A, Mahajon B. Arogyavardhini Vati: A theoritical analysis Journal of Scientific and Innovative Research 2016; 5(6): 225-227.

31. Tripathi B, editor. Sutrasthana; Doshopakramaniya Adhyaya.Vagbhata, Ashatang Hrudaya. Chapter 13, Verse 1-3. Delhi, India: Chaukhamaba Sanskrit Pratishthan; 2015. p. 185. 